\title{
FRACTIONAL URIC ACID EXCRETION AND C-REACTIVE PROTEIN CONCENTRATION IN TYPE 2 DIABETES MELLITUS: THE INFLUENCE OF GLYCEMIC CONTROL
}

\author{
Ekaidem, I.S., ${ }^{a b^{*}}$ Udoh, D.K., Usoh, I.F., Usoroh, A.J.. ${ }^{a}$
}

\author{
Seityjen1@yahoo.com; itemobongekaidem@uniuyo.edu.ng \\ a. Department of Chemical Pathology, Faculty of Basic Clinical Sciences, College of \\ Health Sciences, University of Uyo, Nigeria. \\ b. Institute of Biomedical Research and Innovations, College of Health Sciences, \\ University of Uyo, Nigeria \\ c. Department of Biochemistry, Faculty of Basic Medical Sciences, College of Health \\ Sciences, University of Uyo, Nigeria. \\ d. Department of Medical Laboratory Services, University of Uyo Teaching Hospital, Uyo, \\ Nigeria
}

\begin{abstract}
This study investigated the influence of glycemic control on fractional uric acid excretion and the concentration of C-reactive protein (CRP) in type 2diabetes mellitus. A total of 120 subjects consisting of 76 confirmed diabetic patients, as cases and 44 apparently healthy volunteers served as control, participated in the study. Venous blood and early morning urine were obtained for estimations of CRP, uric acid and creatinine concentrations. The results showed that serum $\mathrm{C}$-reactive protein concentrations were significantly higher in diabetics than in non-diabetic control $(\mathrm{p}=0.000)$ however, serum uric acid, creatinine and uric acid: creatinine ratio were similar in both groups $(p=0.401, p=0.248, p=0.141$ respectively). The fractional excretion of uric acid in diabetics was also significantly higher than non-diabetics. Among the diabetics, patients with positive HbA1c (poorly controlled diabetics) had significantly higher concentration of $\mathrm{C}-$ reactive protein $(\mathrm{p}=0.05)$ and fasting plasma glucose than those with negative HbA1c (better controlled diabetics). However, fractional excretion of uric acid was not significantly different in the HbA1c positive and the negative patients. Pearson bivariate correlation analysis showed that glycated hemoglobin (HbA1c) related positively and significantly with $\mathrm{C}$ - reactive protein among the diabetics $(r=0.333, p=0.003)$ but did not show significant relationship with concentrations of uric acid in serum and urine as well as with fractional excretion of uric acid. Binary logistic regression analysis also showed that a unit increment in the odds of
\end{abstract}


positive $\mathrm{HbA1c}(\mathrm{HbA1c} \geq 6.5)$ was significantly associated with 1.7 -fold increment in $\mathrm{C}-$ reactive protein concentrations $(\mathrm{CI}=95 \%$, Odd ratio $=1.7, \mathrm{p}=0.015)$. However, the concentrations of CRP in diabetic patients were observed to correlate significantly with serum uric acid $(r=0.306, p=0.048)$, urine uric acid $(r=0.397, p=0.000)$ and serum uric acid:creatinine ratio $(\mathrm{r}=0.338, \mathrm{p}=0.012)$; but there was no significant correlation with fractional excretion of uric acid. It can be concluded that the concentration and excretion of uric acid were not significantly affected by glycemic control, however, adequate control of glucose level was observed to modulate the concentration of C-reactive protein.

This study investigated the influence of glycemic control on fractional uric acid excretion and the concentration of C-reactive protein (CRP) in type 2diabetes mellitus. A total of 120 subjects consisting of 76 confirmed diabetic patients, as cases and 44 apparently healthy volunteers served as control, participated in the study. Venous blood and early morning urine were obtained for estimations of CRP, uric acid and creatinine concentrations. The results showed that serum $\mathrm{C}$-reactive protein concentrations were significantly higher in diabetics than in non-diabetic control $(\mathrm{p}=0.000)$ however, serum uric acid, creatinine and uric acid: creatinine ratio were similar in both groups $(\mathrm{p}=0.401, \mathrm{p}=0.248, \mathrm{p}=0.141$ respectively). The fractional excretion of uric acid in diabetics was also significantly higher than non-diabetics. Among the diabetics, patients with positive HbA1c (poorly controlled diabetics) had significantly higher concentration of $\mathrm{C}-$ reactive protein $(\mathrm{p}=0.05)$ and fasting plasma glucose than those with negative HbA1c (better controlled diabetics). However, fractional excretion of uric acid was not significantly different in the HbA1c positive and the negative patients. Pearson bivariate correlation analysis showed that glycated hemoglobin (HbA1c) related positively and significantly with $\mathrm{C}$ - reactive protein among the diabetics $(\mathrm{r}=0.333, \mathrm{p}=0.003)$ but did not show significant relationship with concentrations of uric acid in serum and urine as well as with fractional excretion of uric acid. Binary logistic regression analysis also showed that a unit increment in the odds of positive $\mathrm{HbA1c}(\mathrm{HbAlc} \geq 6.5)$ was significantly associated with 1.7 -fold increment in $\mathrm{C}-$ reactive protein concentrations $(\mathrm{CI}=95 \%$, Odd ratio $=1.7, \mathrm{p}=0.015)$. However, the concentrations of CRP in diabetic patients were observed to correlate significantly with serum uric acid $(\mathrm{r}=0.306, \mathrm{p}=0.048)$, urine uric acid $(\mathrm{r}=0.397, \mathrm{p}=0.000)$ and serum uric acid:creatinine ratio $(\mathrm{r}=0.338, \mathrm{p}=0.012)$; but there was no significant correlation with fractional excretion of uric acid. It can be concluded that the concentration and excretion of uric acid were not significantly affected by glycemic control, however, adequate control of glucose level was observed to modulate the concentration of C-reactive protein.

Keywords: Glycemic control, Glycated hemoglobin, C-reactive protein, Uric acid, Fractional excretion

*Corresponding author: Itemobong Ekaidem ; Department of Chemical Pathology, Faculty of Basic Clinical Sciences, College of Health Sciences, University of Uyo, Nigeria., Institute of Biomedical Research and Innovations, College of Health Sciences, University of Uyo, Nigeria.

Email: seityjen@gmail.com , itemobongekaidem@uniuyo.edu.ng 
Published by IJRP.ORG. Selection and/or peer-review under responsibility of International Journal of Research Publications (IJRP.ORG)

\section{INTRODUCTION}

Uric acid is the acid product of purine metabolism in human, however in most species, it is an intermediate product which is degraded further by the hepatic enzyme uricase to allantoin which then is excreted freely in urine [1]. Elevated uric acid concentration in human has been speculated to contribute to certain chronic medical conditions and disorders such as diabetes mellitus, insulin resistance and high blood premier which have emerged as a major health problem in the industrialized nations [2]. Epidemiological evidence has indicated that the prevalence of hyperuricemia is increasing worldwide with an estimated $5-10 \%$ in adult Americans, $26.1 \%$ in Asian men and $17.0 \%$ in Asian women [3]. An overall prevalence of 25\% was reported in Black Africans [4]. In Nigeria a prevalence of $17.0 \%$ was reported [3]. Hyperuricemia has been made a part of the clusters of metabolic syndrome with abnormalities that include glucose intolerance, dyslipidemia and hypertension [5]. Elevated serum uric acid has been considered an independent risk predictor of obesity, fatty liver and diabetes mellitus. Fructose-induced hyperuricemia was shown to be the cause of insulin resistance and lowering uric acid levels using xanthine oxidase inhibitors was reported to ameliorate the elevation of serum triglyceride and insulin resistance [6].

C-reactive protein (CRP) is a ring-shaped pentameric protein produced by hepatocytes and released into blood circulation in response to inflammatory stimuli such as tumor necrosis factor- $\alpha$ (TNF- $\alpha$ ), interleukin 1 (IL-1) and interleukin 6 (IL-6). CRP is a member of the pentraxin family of proteins and is not related to $\mathrm{C}$-peptide nor protein $\mathrm{C}$. The C-reactive protein gene is located on chromosome 1 (1q23.2) and the protein is made up of 224 amino acid residues, has a monomer molecular mass of 25,106D and has an annular pentameric discoid shape [7].

CRP binds to phosphocholine expressed on the surfaces of dead or dying cells and some bacterial to activate complement system, promoting phagocytosis by macrophages, which cleans necrotic cells and bacteria. It plays a sole in innate immunity as an early defense system against infections. The concentration of CRP at the onset of inflammatory up to 50,000-fold and peaks at 48 hours. Its half-life of 18 hours is constant, and therefore its level is determined by the fate of production and hence the severity of the precipitating cause. CRP is thus a marker for inflammation that can be used to screen for inflammatory conditions. Normal concentrations of CRP in human serum ranges between 5 and $10 \mathrm{mg} / \mathrm{l}$ [8]. Higher levels of $10-40 \mathrm{mg} / \mathrm{l}$ are found in late pregnancy, mild inflammation and viral infection. Values of CRP between $40-200 \mathrm{mg} / \mathrm{l}$ are seen in active inflammation and 
bacterial infections. Severe bacterial infection and burns are characterized by values greater than $200 \mathrm{mg} / \mathrm{l}$ [9].

CRP is a more sensitive and accurate reflection of the acute phase response and returns to normal rapidly in response to therapy. It has been reported that patients with elevated basal levels of CRP are at increased risk of diabetes, hypertension and cardiovascular diseases $[10,11]$. CRP has been shown to exacerbate ischemic necrosis in a complement - dependent fashion and its inhibition can be a safe and effective therapeutic strategy for myocardial and cerebral infarcts [12,13]. Elevations of CRP level is an independent risk factor for atherosclerotic disease and patients with high CRP concentrations are more likely to develop stroke, myocardial infarction and peripheral vascular disease [14]. High level of CRP has been associated with point mutation cys 130 Aug in Apo E gene, coding for apolipoprotein E, thus establishing a link between lipid values and inflammatory markers modulation $[15,16,17]$.

Uric acid has pro-inflammatory activity through the activation of a redox-dependent pro-inflammatory signaling in cultural adipocytes [2]. It regulates the expression of CRP, a marker of inflammation in human vascular smooth muscle cells and endothelial cells. NF$\mathrm{kB}$ is a pro-inflammatory master switch that controls the production of inflammatory markers and mediators. NF-kB activation induced by uric acid has been reported. Soluble uric acid had also been shown to induces inflammatory pathway by activating P38, MAPK and NF-kB in rat vascular smooth muscle cells. Elevated uric acid in serum of diabetic patients was shown to be related to diabetic microvascular and macrovascular complications. Hyperuricemia may be a marker and possibly be responsible for micro vascular damage through inhibition of endothelial nitric oxide synthetize and activation of the serum-angiotensin system [18]. Identifying clinical markers to detect the development and progression of diabetic microvascular complications is critical for early management. This study therefore examined the serum concentrations of CRP and uric acid and serial excretion of uric acid in diabetic patient as they relate to glycemic control.

\section{Materials and methods}

The study was a case-controlled investigation involving a total of 120 subjects consisting of 76 confirmed diabetic patients, seen at the Diabetic Clinic of the University of Uyo Teaching Hospital, as cases and 44 apparently healthy volunteers served as control. The patients were recruited after obtaining an informed consent.

Seven $(7 \mathrm{ml})$ milliliters of fasting venous blood was obtained from each subject using syringe and needle. $2 \mathrm{ml}$ each was dispensed into fluoride oxalate and EDTA bottles while the remaining $3 \mathrm{ml}$ was allowed to clot and retract in a plain sample bottle for extraction of serum. Serum samples were separated into fresh plain sample tube after centrifugation at $3000 \mathrm{~g}$ for 5 minutes in a bench top centrifuge, model 800-1, Zeny Inc. Salt Lake, USA. The serum samples were stored frozen at $-20^{\circ} \mathrm{C}$ until required for analysis of uric acid, creatinine and $\mathrm{C}$-reactive protein concentrations. Urine sample were also collected from participants for estimation of urine uric acid and creatinine concentration. 
Fasting plasma glucose concentrations were determined in the fluoride/oxalate blood sample by glucose oxidase method using Randox glucose reagent kit according to the manufacturer's protocol. Serum and urine creatinine concentrations were determined by the modified Jaffe's reaction method using Randox creatinine reagent kit following the manufacturer's instructions. Similarly, serum and urine uric acid concentration were determined by uricase enzymatic method using Randox uric acid reagent kits.

C-reactive protein concentration in serum was determined by enzyme-linked immunosorbent assay using C-reactive protein ELISA reagent kits from Giesse Diagnostics, Italy. The assay method was based on non-competitive (sandwiched) antibody immunoassay. It was performed according to the manufacture's manual instruction [19]. The glycated hemoglobin (HbA1c) was determined in lysed red blood using reagent kit and the results were expressed percentage hemoglobin [20].

The fractional excretion of uric acid was calculated using the formula FE Ua $=$ Urine Uric Acid $\times$ Serum Creation $\times 100$ Serum Uric Acid $\times$ Urine Creatinine 1

Patients with $\mathrm{HbA} 1 \mathrm{c}=6.5 \%$ were considered as poorly controlled while patients with $\mathrm{HbA} 1 \mathrm{c}<6.5 \%$ were considered to be better controlled [21].

Statistical Analysis: Statistical analysis was performed using SPSS software version 20.0. The results were expressed as mean \pm SD. The differences in parameters between groups was determined by ANOVA post hoc at $\mathrm{P} \leq 0.05$. The relationship between parameters were done using Pearson bivariate correlation and linear logistic regression analysis. Significant differences were considered at $\mathrm{P} \leq 0.05$.

Ethical clearance was obtained from the University of Uyo, Teaching Hospital Research bioethics committee.

\section{Results:}

The influence of glycemic control on uric acid excretion and C-reactive protein concentration were studied among patient with type 2 diabetes mellitus. The result (Table. 1) showed that serum C-reactive protein concentrations were significantly higher in diabetics than in non-diabetic control $(p=0.000)$ however, serum uric acid, creatinine and uric acid: creatinine ratio were similar in both diabetics and non-diabetics $(\mathrm{p}=0.401, \mathrm{p}=$ $0.248, p=0.141$ respectively). The uric acid and creatinine concentrations in urine were significantly lower $(\mathrm{p}=0.042, \mathrm{p}=0.000$ respectively) in diabetics than non-diabetic while the uric acid to creatinine ratios were significantly higher in diabetics than in those without diabetes $(\mathrm{P}=0.001)$. The urine to serum ratio of uric acid and creatinine were also significantly lower in healthy controls subjects while fractional excretion of uric acid was 
significantly higher in diabetics than in control.

Among the diabetic patients (Table. 2), those with positive HbA1c (poorly controlled diabetics) had significantly higher concentration of $\mathrm{C}-$ reactive protein $(\mathrm{p}=$ 0.05) and fasting plasma glucose than those with negative HbA1c (better controlled diabetics). Serum uric acid was lower $(p=0.110)$ and urine uric acid was higher $(p=0.124)$ in $\mathrm{HbA1c}$ positive diabetics than in the negative patients. However, fractional excretion of uric acid was not significantly different in the HbA1c positive patients and the negative patients.

Pearson bivariate correlation analysis showed that the index of glycemic control (HbA1c) related positively and significantly with $\mathrm{C}$ - reactive protein concentrations among diabetics $(\mathrm{r}=0.333, \mathrm{p}=0.003)$ but did not show significant relationship with concentrations of uric acid in serum and in urine as well as with fractional excretion of uric acid. Binary logistic regression analysis also showed that a unit increment in the odds of positive $\mathrm{HbA1c}(\mathrm{HbAlc} \geq 6.5)$ was significantly associated with 1.7 -fold increment in $\mathrm{C}-$ reactive protein concentrations $(\mathrm{CI}=95 \%$, Odd ratio $=1.7, \mathrm{p}=0.015)$. However, the concentrations of CRP in diabetic patients were observed to correlate significantly with serum uric acid $(r=0.306, p=0.048)$, urine uric acid $(r=0.397, p=0.000)$ and serum uric acid:creatinine ratio $(\mathrm{r}=0.338, \mathrm{p}=0.012)$; but there was no significant correlation with fractional excretion of uric acid. Also, mean arterial blood pressure (MAP) of diabetic patients were observed to correlate negatively with serum uric acid and positively with urine uric acid as well as fractional excretion of uric acid. A significant positive association was also observed between CRP and MAP $(\mathrm{CI}=95 \%$, odd ratio $=1.131, \mathrm{p}=0.047)$.

\section{DISCUSSION:}

Adequate glycemic control is the target for successful management of patients with diabetes mellitus and it is an important measure in the preventions of organ and systemic complications of diabetic condition. Glycemic control is usually estimated by the percentage of hemoglobin glycosylation, often referred to as glycated hemoglobin (HbA1c) in red blood cells. This parameter is useful in the assessment of overall glucose status in blood over a period of about 120 days. Thus, well controlled diabetics which was defined as $\mathrm{HbA} 1 \mathrm{c} \leq 6.5 \%$ [20], are less prone to microvascular and macrovascular complications of diabetes mellitus. These complications of diabetes mellitus are known to be the result of metabolic dysfunctions leading to elevated concentrations of certain substances in blood such as glucose, some lipid fractions, insulin, uric acid, C-reactive protein and some inflammatory cytokines [22].

In this study, we examined the concentrations of uric acid and CRP in type 2 diabetic patients relative to control and the influence of glycemic control on serum concentrations of c-reactive protein and uric acid excretion in diabetic subjects. The mean arterial blood pressure (MAP), fasting plasma glucose concentration, CRP and HbA1c were expectedly observed to be higher in diabetic subjects than in non-diabetic control. The 
results of this study are in concert with those reported by various authors in the literature [23].

Although the serum concentration of uric acid and creatinine were similar in both diabetics and non-diabetics subjects, urine concentrations were respectively significantly higher and lower in diabetics than in control subjects. Also, increased fractional excretion of uric acid was observed in diabetics than in control. These findings can be elucidated by the fact that in normal subjects, filtered uric acid is extensively reabsorbed at the proximal tubules and will also be extensively secreted back into the urine hence the higher uric acid in control, whereas in diabetic subjects, the extensive reabsorption of uric acid may not be matched with secretion and thus the decreased concentration of uric acid in diabetic urine and slight increase in serum concentration. This finding in diabetics may probably be due to competition by organic acids in blood that are also transported by the same transporter protein in the kidney tubules. Urine to serum ratio of uric acid and creatinine concentrations were significantly lower in diabetics than in healthy control while fractional excretion of uric acid was significantly higher in diabetics than in control. This shows that although the serum concentrations of uric acid in diabetics and non-diabetics are not different, more uric acid is excreted in urine of diabetics. The decreased concentration of uric acid in urine of diabetics may be the result of rapid elimination due to increased hyper-filtration that characterized early diabetes [24]. This explanation can further be supported by our observation of significant negative correlations among diabetics between mean arterial blood pressure (MAP) and serum uric acid concentration as well as serum uric acid:creatinine ratio; and significant positive correlation between MAP and urine uric acid concentration as well as fractional uric acid excretion. Hyper-filtration, therefore, can increase the overall daily excretion of uric acid especially in the midst of diabetes-induced polyuria and this is manifested by higher fractional excretion of uric acid in diabetics than in normal control subject.

A significantly higher CRP concentration was observed in diabetic patients compared to non-diabetics. This reflects the chronic inflammatory state that characterizes type 2 diabetes mellitus. Also, the concentrations of CRP in poorly controlled diabetics were significantly higher than those in the well-controlled group. This suggest that proper control of glycemic status can modulate the chronic inflammation in patients and thus can reduce the complications associated with the disease. This is further evident by the strong positive correlation between $\mathrm{HbA1c}$, an index of glycemic control, and the concentrations of $\mathrm{C}$ reactive protein among diabetic patients. CRP is an acute phase protein which is significantly elevated during acute and chronic inflammatory processes. Increase in CRP can also be immune-mediated where abnormally glycated proteins in the body are seen by immune cells as altered immunogenic proteins.

The immunological and/or inflammatory processes can result in the release of TNF- $\alpha$ and IL -6 which is turn will cause the synthesis and release of CRP into circulation. And uric acid had been shown to have pro-inflammatory activities by inducing NADP-oxidase 
activation through a redox-dependent pro-inflammatory signaling in cultured adipocytes $[25,26]$. Uric acid upregulates the expression of CRP in human vascular smooth muscle cells and NF-kB activation induced by uric acid have also been reported [26]. In this study, even though serum uric acid concentration showed no significant correlation with CRP, a significant positive correlation was observed when the serum uric acid concentration was corrected with serum creatinine. This may suggest an association between CRP and elevated uric acid level in the pathogenesis of diabetic complications, especially in patients where the excretion of uric acid is compromised by kidney damage.

\section{Conclusion}

Although the serum concentrations and the excretion of uric acid were not significantly affected by glycemic control, adequate control of glucose level in diabetic patients was observed to modulate the concentration of $\mathrm{C}$-reactive protein and therefore the chronic inflammatory activities associated with type 2 diabetes. This may contribute in reducing the risk of microvascular and macrovascular complications of this condition.

Tables Table 1: Physiological and biochemical characteristic of diabetic and non-diabetic subjects in the study groups

\begin{tabular}{|c|c|c|c|}
\hline Parameter & Diabetics $(n=75)$ & Non-Diabetics $(n=25)$ & $p$-Value \\
\hline MAP (mmHg) & $92.76 \pm 8.74$ & $84.93 \pm 4.42$ & 0.000 \\
\hline Age (years) & $54.89 \pm 10.64$ & $54.52 \pm 13.40$ & 0.887 \\
\hline $\begin{array}{l}\text { Plasma glucose } \\
(\mathrm{mmol} / \mathrm{L})\end{array}$ & $9.04 \pm 2.61$ & $4.62 \pm 0.64$ & 0.000 \\
\hline CRP (mg/L) & $8.25 \pm 3.31$ & $3.99 \pm 1,72$ & 0.000 \\
\hline $\begin{array}{l}\text { Serum uric acid } \\
\text { (umol/L) }\end{array}$ & $396.53 \pm 123.94$ & $373.60 \pm 95,78$ & 0.401 \\
\hline $\begin{array}{l}\text { Serum creatinine } \\
\text { (umol/L) }\end{array}$ & $93.49 \pm 22.00$ & $99.44 \pm 22.58$ & 0.248 \\
\hline $\begin{array}{l}\text { Urine uric acid } \\
\text { (umol/L) }\end{array}$ & $289.60 \pm 87.33$ & $387.60 \pm 73.50$ & 0.042 \\
\hline $\begin{array}{l}\text { Urine creatinine } \\
\text { (umol/L) }\end{array}$ & $684.59 \pm 333.98$ & $1337.96 \pm 606.29$ & 0.000 \\
\hline $\begin{array}{l}\text { Serum uric acid / } \\
\text { creatinine ratio }\end{array}$ & $4.38 \pm 1.48$ & $3.90 \pm 1.14$ & 0.141 \\
\hline $\begin{array}{l}\text { Urine uric acid / } \\
\text { creatinine ratio }\end{array}$ & $0.48 \pm 0.26$ & $0.30 \pm 0.15$ & 0.001 \\
\hline HbA1c (\%) & $8.03 \pm 2.48$ & $4.34 \pm 0.89$ & 0.000 \\
\hline $\begin{array}{l}\text { Fractional excretion } \\
\text { of uric acid }\end{array}$ & $11.67 \pm 4.67$ & $8.24 \pm 4.51$ & 0.019 \\
\hline
\end{tabular}

Dara are expressed as mean $\pm \mathrm{SD}$, significant difference is considered at $\mathrm{p}<0.05$. 
$\mathrm{MAP}=$ Mean arterial blood pressure, $\mathrm{CRP}=\mathrm{C}$ - reactive protein

Table 2: The effects of glycemic control on some biochemical characteristics of good controlled and poorly controlled diabetic subjects

\begin{tabular}{|l|c|c|c|}
\hline Parameter & $\begin{array}{c}\text { Diabetics with good } \\
\text { glycemic control }(\mathrm{n}=25)\end{array}$ & $\begin{array}{c}\text { Diabetics with poor } \\
\text { glycemic control }(\mathrm{n}=48)\end{array}$ & p-Value \\
\hline MAP (mmHg) & $90.78 \pm 8.02$ & $93.65 \pm 8.98$ & 0.214 \\
\hline $\begin{array}{l}\text { Plasma glucose } \\
\text { (mmol/L) }\end{array}$ & $7.35 \pm 1.58$ & $9.57 \pm 2.65$ & 0.004 \\
\hline CRP (mg/L) & $5.58 \pm 3.28$ & $9.91 \pm 2.83$ & 0.049 \\
\hline $\begin{array}{l}\text { Serum uric acid } \\
\text { (umol/L) }\end{array}$ & $425.88 \pm 131.48$ & $381.35 \pm 124.13$ & 0.110 \\
\hline $\begin{array}{l}\text { Serum creatinine } \\
\text { (umol/L) }\end{array}$ & $93.00 \pm 25.88$ & $92.56 \pm 19.75$ & 0.383 \\
\hline $\begin{array}{l}\text { Urine uric acid } \\
\text { (umol/L) }\end{array}$ & $264.71 \pm 132.58$ & $299.42 \pm 113.78$ & 0.124 \\
\hline $\begin{array}{l}\text { Urine creatinine } \\
\text { (umol/L) }\end{array}$ & $646.65 \pm 444.95$ & $707.40 \pm 298.63$ & 0.420 \\
\hline $\begin{array}{l}\text { Serum uric acid / } \\
\text { creatinine ratio }\end{array}$ & $4.93 \pm 1.96$ & $4.20 \pm 1.34$ & 0.0 .142 \\
\hline $\begin{array}{l}\text { Urine uric acid / } \\
\text { creatinine ratio }\end{array}$ & $0.52 \pm 0.32$ & $0.46 \pm 0.23$ & 0.648 \\
\hline HbA1c (\%) & $5.45 \pm 0.47$ & $9.07 \pm 2.22$ & 0.000 \\
\hline $\begin{array}{l}\text { Fractional excretion } \\
\text { of uric acid }\end{array}$ & $9.76 \pm 5.17$ & $12.37 \pm 5.74$ & 0.134 \\
\hline Dara are expressed as & and & & \\
\hline
\end{tabular}

Dara are expressed as mean $\pm \mathrm{SD}$, significant difference is considered at $\mathrm{p}<0.05$.

$\mathrm{MAP}=$ Mean arterial blood pressure, $\mathrm{CRP}=\mathrm{C}$ - reactive protein

\section{References}

1. Cammalleri, L., Malaguarnera, M., Rasburicase represents a new tool for hyperuricemia in tumor lysis syndrome and in gout. Int J Med Sci 2007; 4(2):83-93. doi:10.7150/ijms.4.83. Available from http://www.medsci.org/v04p0083.htm

2. Nejatinamini, S., Ataie-Jafari, A., Qorbani, M., Nikoohemat, S., Kelishadi, R., Asayesh, H., et al. Association between serum uric acid level and metabolic syndrome components. J Diabetes Metab Disord. 2015;14:70 
3. Smith E, March L. Global prevalence of hyperuricemia: a systematic review of population-based epidemiological studies https://acrabstracts.org/abstract/globalprevalence-of-hyperuricemia-a-systematic-review-of-population-basedepidemiological-studies/. Arthritis Rheumatol. 2015;67

4. Moulin, S.R., Baldo, M.P., Souza, J.B., Luchi, W.M., Capingana, D.P., Magalhaes, P., Mill, J.G., Distribution of Serum Uric Acid in Black Africans and Its Association with Cardiovascular Risk Factors The Journal of Clinical Hypertension 2017; 19(1): $45-50$

5. Xiong, Q., Liu, J., Xu, Y. Effects of Uric Acid on Diabetes Mellitus and Its Chronic Complications International Journal of Endocrinology. 2019; 2019: Article ID 9691345, https://doi.org/10.1155/2019/9691345

6. Shirakura, T., Nomura, J., Matsui, C., Kobayashi, T., Tamura, M., Masuzaki, H. Febuxostat, a novel xanthine oxidoreductase inhibitor, improves hypertension and endothelial dysfunction in spontaneously hypertensive rats. Naunyn-Schmiedeberg's Arch Pharmacol (2016) 389:831-838 DOI 10.1007/s00210-016-1239-1

7. Thompson, D., Pepys, M.B., Wood, S.P. The physiological structure of human Creactive protein and its complex with phosphocholine. Structure (1999) 7(2):16977. doi:10.1016/S0969-2126(99)80023-9

8. Krishnan, S., Setty, Y., Betal, S.G., Vijender, V., Rao, K., Dampier, C., Stuart, M. Increased levels of the inflammatory biomarker C-reactive protein at baseline are associated with childhood sickle cell vasocclusive crises. British Journal of Haematology, 2009; 148: 797-804

9. Du Clos, T.W., Mold, C. C-reactive protein: an activator of innate immunity and a modulator of adaptive immunity. Immunol Res 2004; 30(3):261-77. doi:10.1385/IR:30:3:261

10. Venugopal, S.K., Devaraj, S., Yuhanna, I., Shaul, P., Jialal, I. Demonstration that Creactive protein decreases eNOS expression and bioactivity in human aortic endothelial cells. Circulation 2002; 106(12):1439-41. doi:10.1161/ 01.CIR.0000033116.22237.F9

11. Singh, U., Devaraj, S., Vasquez-Vivar, J., Jialal, I. C-reactive protein decreases endothelial nitric oxide synthase activity via uncoupling. J Mol Cell Cardiol 2007; 43(6):780-91. doi:10.1016/j.molcel.2007.06.030

12. Yasojima, K., Schwab, C., McGeer, E.G., McGeer, P.L. "Generation of C-reactive protein and complement components in atherosclerotic plaques," The American Journal of Pathology, 2001; 58(3): 1039-1051.

13. Thiele, J.R., Zeller, J., Bannasch, H., Stark, G.B., Peter, K., Eisenhardt, S.U. Targeting C-Reactive Protein in Inflammatory Disease by Preventing Conformational Changes Mediators of Inflammation 2015; Article ID 372432, 9 http://dx.doi.org/10.1155/2015/372432 
14. Schwedler, S.B., Kuhlencordt, P.J., Ponnuswamy, P.P., Hatiboglu, G., Quaschning, T., Widder, J., et al. Native C-reactive protein induces endothelial dysfunction in ApoE-/- mice: implications for iNOS and reactive oxygen species. Atherosclerosis 2007; 195(2):76-84. doi:10.1016/j.atherosclerosis.2007.06.013

15. Pepys, M.B., Hirschfield, G.M., Tennent, G. A. et al., "Targeting C-reactive protein for the treatment of cardiovascular disease," Nature, 2006; 440(7088):1217-1221.

16. Russo, G.T., Giandalia, A., Romeo, E.L., Alibrandi, A., Horvath, K.V., Asztalos, B.F., Cucinotta, D. Markers of Systemic Inflammation and Apo-AI Containing HDL Subpopulations in Women with and without Diabetes International Journal of Endocrinology 2014, Article ID 607924, 9 http://dx.doi.org/10.1155/2014/607924

17. Hubacek JA, Peasey A, Pikhart H, Stavek P, Kubinova R, Marmot M, et al. APOE polymorphism and its effect on plasma $\mathrm{C}$-reactive protein levels in a large general population sample. Hum Immunol. 2010;71:304-308. doi: 10.1016/j.humimm.2010.01.008.

18. Waring, W.S., Webb, D.J., Maxwell, S.R. Effect of local hyperuricemia on endothelial function in the human forearm vascular bed. $\mathrm{Br} J$ Clin Pharmacol. 2000;49:511.

19. Pektaş, A., Olguntürk, R.,Kula, S., Cilsal, E.,Oguz, A.D., Tunaoğlu, F.S. Biomarker and shear stress in secondary pediatric pulmonary hypertension Turk J Med Sci 2017; 47: 1854-1860 doi:10.3906/sag-1609-13

20. John, W.G. Use of HbA1c in the diagnosis of diabetes mellitus in the UK. The implementation of World Health Organization guidance 2011. Diabet Med. 2012;29(11):1350-1357

21. WHO (2011) Use of Glycated Haemoglobin (HbA1c) in the Diagnosis of Diabetes Mellitus. World Health Organization. http://www.who.int/cardiovascular_diseases/reporthba1c_2011_edited.pdf

22. Sproston, N.R., Ashworth, J.J. Role of C-Reactive Protein at Sites of Inflammation and Infection. Front. Immunol. 2018; 9:754. doi: 10.3389/fimmu.2018.00754

23. Alberti KG, Zimmet P, Shaw J. International Diabetes Federation: a consensus on Type 2 diabetes prevention. Diabet Med, 2007, 24:451-463.

24. Okada, R., Yasuda, Y., Tsushita, K. , et al. Glomerular hyperfiltration in prediabetes and prehypertension Nephrol Dial Transplant 2012; 27:1821 - 1825.

25. Lu W., Xu Y., Shao X., Gao F., Li Y., Hu J., Zuo Z., Shao X., Zhou L., Zhao Y., et al. Uric Acid Produces an Inflammatory Response through Activation of NF- 
kappaB in the Hypothalamus: Implications for the Pathogenesis of Metabolic Disorders. Sci. Rep. 2015;5:12144. doi: 10.1038/srep12144.

26. McGeough M.D., Wree A., Inzaugarat M.E., Haimovich A., Johnson C.D., Pena C.A., Goldbach-Mansky R., Broderick L., Feldstein A.E., Hoffman H.M. TNF regulates transcription of NLRP3 inflammasome components and inflammatory molecules in cryopyrinopathies. J. Clin. Investig. 2017;127:4488-4497. doi: 10.1172/JCI90699 